\title{
The translation of Psalm 89:13 and its implications
}

\author{
Pieter M Venter \\ Department of Old Testament Studies \\ University of Pretoria
}

\begin{abstract}
Psalm 89:13a can be translated: "You created north and south." However, it can also be translated as "Zaphon and Yemin you created," In the former case the phrase is seen as an indication of the extensiveness of the earth. In the latter the translation points to the mythological form of the hymn section (Ps 89:2-19) in which it appears. This article chooses for the mythological alternative and substantiates this position from the northern toponyms used in the hymn and the hymn's obvious mythological structure.
\end{abstract}

\section{INTRODUCTION}

The two poetic lines in Psalm 89:13 present problems for translators. Psalm 89:13 reads as follows in the Hebrew Masoretic Text:

\section{$\mu t$ a r b ht a $\div$ ymyw \pm ND $x$

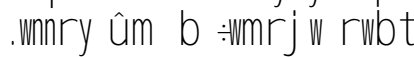

The translation of the second line presents no problems. In all English translations it is translated as the mountains Tabor and Hermon rejoicing in the Lord's name. Translations, however, differ on the first line. Some translate the line as "north and south you created". Others translate it as toponyms: "Zaphon and Yemin you created."

The problem we deal with in Psalm 89:13 is whether toponyms are found in the second line only or also in the first line. Toponyms in poems are not only indications of geographical locality. From his/her perspective the poet constructs a text world that differs from the world of the reader. In consciously organised poetic texts the reader has to discover what Seybold (2003:214) calls the "immanenten Kontruktionspläne" the poet used if he/she wants to construct a "Sinnraster" for himself of what the poet intends with his text. The structures poets use in Psalms are either spatial or chronologic. The spatial 
world of the text indicates the position from which the poet views and understands the world. It can be clearly determined in texts linked to fixed structures like the sanctuary and its cult. According to Seybold (2003:225), however, texts with other spatial orientations are more complicated as they are more artful. Among these can be counted texts with "geographischen Referenzen" (Seybold 2003:225) like Psalms 29, 42, 48, 60, 72, 76, 83, 84, $89,120,122$ and 125 . The viewpoint of the poets in these texts is conceptualised in terms of the specific geographical references they associated these places with.

All communication has a degree of cultural loading (cf Kavanagh 2000:99-118). Cultural perspectives are always present in names of places. In the production and reading of the text "cognitive frames" (Wilt 2002:152) played an important role. In translating texts a "principle of iconicity" (cf Wilt 2002:154) is present and the translation should bear an iconic resemblance to the original. Sociolinguistics will have to play a part in deciding how Psalm 89:13a has to be translated.

This decision can benefit from the discipline of Critical Spatiality. This approach seeks "to reintroduce spatiality in an ontological trialectic that includes historicality, sociality, and spatiality" (Flanagan1999:26). Toponyms or geographical locations with their specific names are not only perceived as concrete geophysical realities (what Matthews 2003:12 calls "first space"), but also as space which is conceived ("second space") related to the ideology of the author and of the society to which it belongs ("third space"). This approach can help us to reconstruct the frame of reference of the hymn's poet and offer a solution for the translation of verse 13 .

\section{PSALM 89 VERSE 13}

Mount Hermon is located at the northern boundary of the biblical Palestine. It marks the southern terminus of the Anti-Lebanon Range. According to Saur (2004:164) Hermon never really belonged to the area where Israel once settled. It was, however known as a "Göttersitz" (Saur 2004:164). According to Arav (1992:158-160) more than twenty temples have been surveyed in this area. In the Bible it is associated with religious activity. Reference to BaalHermon in Judg 3:3 may indicate that it was once a major Canaanite sanctuary (cf also1 Chr 5:23). Its history as a sacred site is probably reflected in the name $=4 m r$ $h$. If this name was derived from $\mu \mathrm{r} j$ the name Hermon probably meant "a sacred mountain", or "consecrated place." In the much younger Book of the Watchers (1 Enoch 1-36) Hermon, Dan and Abel-Main are explicitly named as areas of religious activity. In both the Testament of Levi (2-7) and 1 Enoch 13-14 revelatory events take place in the geographical setting of Abel-Main and Mount Hermon. References to places in the Lebanon-Huleh-Hermon triangle "constitute a tradition of northern Galilean 
provenance which, in turn, reflects visionary activity in the area of Dan and Hermon" (Nickelsburg 1981:585). In the development of Israel's religion and its conflict with other religions, inter alia the Baal religion associated with the northern areas, Hermon was a keyword in Israel's ideology. From all of this information we can conclude that the name Hermon therefore not only indicates a physical location but also functions as reference to religious activity. The name therefore indicates "second space" in critical spatial terms.

The isolated hill of Tabor is a prominent landmark in the Jezreel Valley. The troops of Zebulun and Naphtali gathered at Tabor for their victorious action under the leadership of Deborah and Barak (Judges 4:6). It could have been a cult centre as well. While Tabor forms a landmark in Joshua 19:22, Judges 4:6, 12, 14, Jeremiah 46:18, 1 Chronicles 6:62 and 1 Samuel 10:3, it is used in a cultic connotation in Hosea 5:1. The reference to the princes of Zebulun and Naphtali in Psalm 68:27 reflects a cultic setting for Tabor. The possibility was already pointed out by Mowinckel that Psalm 68 was drawn from liturgies of the temple in Jerusalem. These liturgies in turn had a SyrianCanaanite origin in the north of Israel. The reference to Lebanon, Sirion and Kadesh in Psalm 29 also indicates the use in the Jerusalem cult of a Baalhymnus from the old sanctuary at Dan near Hermon (cf Venter 2004). Tate (1998:220) reminds of Gray's (1977:2-26) theory that the name Tabor refers to material that was derived originally from the liturgy of an autumn festival held on Mount Tabor (cf Ps 68). Tabor was a boundary sanctuary between Zebulun, Issachar, and Naphtali (Dt 33:18-19; Josh 19:34). Also in the case of the name Tabor a second space connotation can be indicated.

This observation that the toponyms Hermon and Tabor indicate more than mere geographical landmarks in Israel can be helpful when we translate the first line of verse 13 . The toponyms in line two are referring to ancient cultic centres in the north. At the background of the reference there is probably an ideological conflict with Syrian-Canaanite religion traditions. They come from a "Theophanietradition" (Seybold 2003:272).

The combination Iymyw $\mathrm{n} x$ in line one does not occur elsewhere in the Hebrew Bible. In Psalm 107:3, Isaiah 49:12, and the Aramaic of Daniel 8:4 $\mu \mathrm{y}$ is found in combination with $\operatorname{mp} \times$ (cf Lisowsky 1958:1227-8). Koehler \& Baumgartner (1958:384) give two probable meanings for the phrase in Psalm 89:13. It is either "Bergname oder Ersatz dafür", referring to Eissfeldt's "Baal Zaphon", or "die rechte Seite ist die südliche Seite", so that the combination indicates "Nord u. Süd". Both geographical indications as well as geographical designations are linked to the word pair.

In the Septuagint ( $L X X$ 88:13) the word pair is translated as tòv Boppồ kaì $\theta \alpha \lambda \alpha \sigma_{\sigma} \sigma \alpha \varsigma$. This indicates that Hebrew text used for the Greek 
translation probably had $\mu$ y rather than the Masoretic tymy. This could have been the reason why it was translated as $\theta \alpha \lambda \alpha^{\prime} \sigma \sigma \alpha$. In its text critical apparatus the BHS (Rudolph \& Rüger 1984:1171) indicates qal assa as the translation used in the original Septuagint, the Codex Alexandrinus, the recension of Lucianus and the Codex Parisinus Latinus. BHS does not, however refer to any Hebrew manuscript containing a reading $\mu$ y (without the final yod and $\min$ ). The Septuagint therefore understands the word pair to refer to the north and the sea/west/south.

Translations like the King James Version, American Standard Version, New King James Version, Good News Bible, New Living Translation and English Standard Version translate the phrase as "north and south." The New Revised Standard Version translates it as "north and south", but includes the alternative "Zaphon and Yamin" in brackets. The New American Bible translates it as "Zaphon and Amanus you created" without giving any alternative. When the word pair is translated as merely "north and south" and read together with the names Hermon and Tabor in the second line, it is interpreted as indication of the totality of God's creative acts and power (cf Coetzee 1995). It refers to the wind directions and the high mountains. This translation would accommodate the aspect of first space using physical indication of space as metaphor to conceptualise the Lord's extensive power. The aspect of perceived second space indicated above is then totally ignored. When the cultic aspect and religious conflicts reflected in these names are taken in to account the facet of second space should be reflected in the translation.

Petersen (1982:172) proposes to link verse 13a to the previous verse 12b. This highlights the parallelism between "the world and all that is in it, you have founded them" $(12 b)$, and the synonymous line "the north and the south, you have created them" in the directly following line of 13a. Verse 12a could even be read as two separate lines (to you heavens belong // also to you belongs earth) having internal synonymous parallelism. The result would be, however, that verse $13 \mathrm{~b}$ will be isolated without any parallel line. Verse $13 \mathrm{~b}$ cannot be divided in any way to form two lines like 12a. Neither will there be any logic poetic link to any other line. Even if verses 12 and 13 are taken together to form a four-line couplet, verse $13 \mathrm{~b}$ does not coincide with verse 12 a to form an inclusio.

Another possibility is to read Tabor and Hermon in terms of the first line as indication of east and west. This does not make any sense, because physically these two mountains are rather found on a north-south axis than an east-west axis. 
Some like Dahood and Krauss translate the word pair as geographical designations of still two more mountains. Parallel to Tabor and Hermon tymyw in $X$ are designations of mount Zaphon and mount Yamin/Amanus. Zaphon would then refer to Mount Casius (dzebel el-akra'), the mountain home of Baal at Ugarit. According to Krauss (1966:342-3) Zaphon as the Near Eastern Olympos is a name from the "Uralten Kulttraditionen ... die grösstenteils schon in vorisraelitischer Zeit im syrisch-kanaanäischen Raume eine im einzelnene kaum noch durchschaubare 'Überlieferungsgeschichte' erlebten." This can probably be the mountain where the gods assemble in the far reaches of the north to which Isaiah 14:13 refers. When Psalm 48:3 calls Zion $\operatorname{tp} x$ yt kr y ("the remotest parts of the north") it shows that ancient SyrianCanaanite names and mythology from the north were carried over to Jerusalem. When the problematic tymy is read as tma or $h n m a$ it can be linked to Amanus, a spur of the Taurus mountains or the Anti-Lebanon range. This name is used along with Shenir and Hermon in Song of Songs 4:8. No text critical proof can, however, be given for this change in the text.

Saur (2004:164 n 40) refers to Emmendörffer, Hossfeld and Seybold who all read the verse as referring to four "Götterberge". Saur (2004:164-165) himself understands it as references in a "vorliegende Textfassung" to actual mountains which were changed in the tradition process to indicate an allinclusive praise by the mountains that include all of the earth in its north-south expansion. Saur's (2004:165) criticism is that a translation of four mountains removes the differentiation in the two lines between God's creation of the north-south expansion and the praise presented by the mountains Hermon and Tabor.

Scholars who translate the verse as four mountains actually work with the idea of second space. Not only the names of the mountains are important for them, but also the fields of association indicated by these names. These mountains are associated with northern traditions of worship. Specific northern toponyms are used because they bear a traditional meaning. The belief is expressed in these lines that these mountains are under the lordship of Yahweh. He created them and they are in his service as cultic sites where he is praised. It reflects a polemical trend to give counter testimony to the Baal religion. Even more than that, not only second space is indicated but also an ideological third space. For Krauss (1966:620) these "Götterberge" Zaphon, Yamin/Amanus, Tabor and Hermon reflect "Auseinandersetzungen Israels mit den Göttern und Götternberges der kanaanäischen Urbevölkerung". This polemical intention links to Goulder's (1982:214) suggestion that the hymn part of Psalm 89 originally came from the cult centre on Mount Tabor. From there it was transferred to the sanctuary at Dan, which was at the foot of 
Mount Hermon. That would be the reason why specific northern toponyms are used in this verse.

The idea that second and third space is implied in these names and that it should be reflected in the translation is to be substantiated next by spatial analysis of the larger context in which the lines 89:13 are used.

\section{THE HYMN (89:6-19)}

Psalm 89 consists of a Hymn (verses 2-3, 6-19), an Oracle (verses 3-4, 2038) and a Complaint (verse 39-52). Verse 13 forms part of the hymn. Our critical spatial analysis has to be extended to the rest of the hymn in which the verse is found if we want to proof our thesis that a translation of the verse has to reflect the mythical background of the northern toponyms in the verse. The hymn (89:6-19) is framed by the keywords "Yahweh" (6a 19a) and "holy" (6b 19b) (cf Hossfeld 2000:588). These words indicate the boundaries of the unit. In the hymn Yahweh is praised as the King of Heaven, the incomparable God, the creator, the ruler and the facilitator of all of history (cf Weber 2003:111).

Saur (2004:158) indicates that all of Psalm 89 contains older "Überlieferungsmaterial" that have been integrated in the final song. The clearest indication of the use of such material can be seen in the hymn. According to Saur (2004:160) the presentation of Rahab and the creation of the world in this older tradition indicate the exilic or early exilic time as the stage at which the material was integrated in the psalm.

The hymn can be subdivided on metrical and stylistic grounds and in terms of contents into four strophes:

- 6-9 God's heavenly throne,

- 10-13 Chaoskampf and Creation,

- 14-15 Yahweh's acts and faithfulness,

- 16-19 The people.

Saur (2004:162) indicates a spatial as well as a chronological movement in the hymn: "Geographisch führt die Bewegung des Hymnus von oben nach unten; chronologisch besingt der Hymnus überzeitliche, urzeitliche und historische Konstellationen." This spatial movement from high above to down below is very important for our spatial analysis. Spatiality plays a definite role in the construction of the hymn. The movement from God's heavenly abode down to the earth passes through the Götterberge described in verse 13. To indicate this larger spatial context of verse 13 we shall now discuss it within the context of the second strophe. This strophe is the central strophe of the 
hymn. Next we shall compare this strophe with the other three strophes of the hymn to indicate the ideological spatial context of the verse.

\subsection{Chaoskampf and creation (89:10-13)}

This strophe forms the focus of the hymn. It is the high point of the praise in the previous strophe (89:6-9). It also provides the reason for the people's joy and praise in the third (89:14-15) and the fourth strophes (89:16-19). It functions as the king pin of the hymn working with both cosmic space and Urzeit.

The use of the emphatic "you" at the beginning of verses 10 and 11 , the possessive "to you" or "yours," at the beginning of verse 12 and again the emphatic "you" in verses 12b, 13a, and "your" in verse 13b, characterise this strophe. It shares the emphatic "you" with Psalm 74:13-17 and have a "gewisse Ähnlichkeit" (Petersen 1982:174) with it. In both the submission of the sea and the creation of the cosmos it plays a central role. God is depicted here in terms of the cosmos which he created and which he rules. Cosmic space is utilised to express who Yahweh is and what he does. Cosmic space is used not only to indicate a physical entity here. It is also used as ideological indication to metaphorically describe who Yahweh really is. The physical creation exists of sea (10-11), heaven and dry land (12-13). The sea is not only viewed as a collection of water but foremost as an opposing force with mythic residents like Rahab. Elsewhere Leviathan and Tanin (the sea monster) are named along with Rahab as mythic inhabitants of the sea (Job 9:13; 26:12; Ps 74:14, 87:4; Is 30:7; 51:9). Yahweh fights against these chaotic forces of the sea and its powerful residents. He subdues them (cf Ps $65: 8 ; 74: 16 ; 93: 3 f)$. He is the Chaoskämpfer. His sovereign powers is conceptualised in terms of this mythical theme of triumph over the Urchaos with its mythical monsters in the Urzeit.

In the themes of submission and creation, Petersen (1982:175) finds and indication of the independent compilation of "... verschiedenen Einzelthemen bestehende mythischen Motivzusammenhangs." These are combined to substantiate and illustrate Yahweh's superiority and uniqueness in relation to all other powers and beings. In the Canaanite myth of Baal who established his kingship by overcoming Yam (Sea) exactly the same idiom occurs. Here as well Yahweh's conquest of the raging sea and its forces is used to depict his cosmic ruler ship. In both the Yam myth and here mythical spatial terms are used to conceptualise the god's sovereignty.

According to Terrien (2003:8) Canaanite sacred poetry had a larger influence on the Psalms than Egyptian and Mesopotamian literature. It "served as a model for the prosodic techniques of the Hebrew musician. 
During the long years of the Israelite tribes' infiltration into the land of Canaan the oldest psalmists were taught by the Canaanite musicians who served in such sanctuaries as Dan, Bethel, Shechem, Shilo and eventually Jebus, when Jerusalem became at last the capital of Israel under David and Solomon." Mosca's (1986) theory is that the author of Daniel used original Ugaritic Baal material with an enthronement scene in which Baal, rider of clouds, approaches $\mathrm{El}$, the whitehead father of years to compose the heavenly figure in Daniel 7. He used the extant hymn in Psalm 89:6-19 for his composition. This hymn along with Psalm 8, according to Mosca, represents an intermediate stage between the original Baal material and the eventual use of the expression "son of man" in Daniel 7. In Mosca's (1986:510) mind this hymn with its primeval victory and establishment of the world "... reflects the patterned movement of the Baal cycle: revolt and defeat of Yamn, the movement of the storm god to Zaphon, Baal's entronement there, and the proclamation of the kingship."

Another clue to the origin of this material comes from the study of the literary growth of Psalm 29. In this psalm traditional Baal and El elements occur. Yahwe's identity is conceptualised there by using properties of Baal in the Ugaritic Baal-Yam myth (cf Kloos 1986:123). In the central parts of Psalm 29 traditions of the storm god Baal Hadad are used while mainly El traditions are found in the surrounding parts. According to Jeremias (1987:42 n 39) an original hymn on Baal's reign from the mountain of Zaphon from northern provenance was used for the middle section of Psalm 29 as indicated by the geographical terms Lebanon, Sirion and Kadesh of the Syrian Desert. Seybold's (1998:121) theory is that a mythical hymn comprising of seven theologumena on Baal Hadad the storm god was changed into a theophany liturgy to depict Yahweh as the Cosmic King who has the power to rule the thunder, the primeval ocean, the land, the desert and all creatures. The same tendency is found in Psalm 93 and the Sumerian-Accadian amatu hymns. Seybold (1998:99) sees the old Israel sanctuary at the foot of Hermon near Dan as the place where this transformation took place. The indication of northern localities such as Lebanon points to a northern provenance of the basic material used in the psalm. At sanctuaries like Dan they had immediate contact with Baalism and could have used Baal notions to express their ideas on Jahwe. Their conceptualisation probably developed at the sanctuary at Dan and related to revelatory sites in the surroundings like Lebanon, Sirion and Kadesh. Here nature as well as mythological spatiality was used. These formulations already in existence at the sanctuary of Dan explicitly formulated for cultic purposes were later taken over in Jerusalem and applied to the temple there (cf Dt 32 and Ps 78). The mythological spatiality used in 89:10- 
11, expressed in north-south/Zaphon and Amuna indications, and the explicit northern toponyms Tabor and Hermon used in the second line, also points to literature of northern provenance conceptualised in typical mythical Baal language.

Saur (2004:164) follows Gunkel (1981-1995, III:583-587) and links this strophe to the battle between Marduk and Tiamat in Table IV of the Babylonian creation epic Enuma Elish. As no equivalent of Rahab can be found in the neighbouring Ugaritic literature, while large differences can be indicated between the sexually different Rahab and Tiamat, Saur (2004:164) supposes "einem komplexen Enstehungsprozess" in which Mesopotamian and Canaan traditions were merged together over a wide geographical area over a long time.

The cosmic space in verses $12-13$ is that of heaven and earth. These are described in terms of space that God created. He founded ( $d s y)$ and created ( $a r b$ ) them. No mythological language referring to opposing cosmic powers is used here to describe God's relation to them. The space on earth is described in terms of compass directions (north and south) and mountains from the northern areas. The cultic and ideological connotations of Tabor and Hermon, however, indicated above to us that we are not merely dealing with first space language here. We are dealing here with polemics against the Syrian-Canaanite mythical Baal religion that stripped the earth of any opposing mythical power. Even if the word pair north-south is used in the translation, Hossfeld (2000:591) still thinks "Hinter der Himmelsrichtungen, vor allem in der Verbindung mit Tabor und Hermon, stehen aber die traditionelle ugaritischen Götterberge Zafon und Amanus in der Nähe der Stadt Ugarit, die neben dem Hermon als Wohnsitz Els auftauchen," Although no mythical language is found here as in verses 10-11, the background of the reference to the mountains Tabor and Hermon (and Zaphon and Amuna as it should be translated) is the mythical conceptions of the god who subdued the mythical powers and who is worshipped at mountain sanctuaries. The praise of God is still conceptualised in terms of the "Götterberge" Tabor and Hermon.

An effort to read something typical Israelite into the central strophe of 10-13 is to understand Rahab in verse 11 in terms of Psalm 87:2, Isaiah 30:7 and 51:9-10, as a metaphor for Egypt. Rahab then indicates the historical event in the exodus theme when Israel crossed the Sea of Reeds. Verse 11 is then interpreted as moving from God's achievement over mythical powers to his historical achievements. According to Hossfeld (2000:591), "Die V10-11 oszillieren also zwischen Schöpfungs- und Geschichtswirken JHWHs." This interpretation cannot be supported. The exodus theme does not occur in this psalm. There is no internal witness in these verses to read a combination of 
mythical and historical themes here as it is for instance found in Isaiah 51:910. I would rather read this strophe as conceptualising Yahweh in mythical cosmic spatial terms as well as anti-mythical cosmic spatial terms. Both operate on a third space level to express Israel's faith in opposition to traditional Baal religious concepts.

This strophe thoroughly substantiates a mythical context for verse 13 and invites a translation in those terms.

\subsection{God's heavenly throne (89:6-9)}

In the verses of this first strophe of the hymn a heavenly scenario is depicted. The depicted space is the mythical heaven and its inhabitants. Yahweh is surrounded by a heavenly host. They are called "assembly of holy ones" ( $\mu y v d q \mid h q, 89: 6)$, "children of gods"( $\mu y \mid$ a ynb , 89:7; cf Ps 29:1, 82), "council of holy ones"( $\mu$ y $d q A d$ v6, 89:8) "those that surround God" (89:8). The Lord is called "God of hosts" (89:9). He is the leader of these heavenly residents. No one in this heavenly entourage can be compared to the Lord (89:7a, 7b). Although he is feared by all and awesome above them all, all of heaven praises him. The reason being that his ruler ship is marked by his faithfulness (ût numa $)^{1}$ towards all of them. He acts in a conscientious way. There is inner stability and consistency in his sovereignty over them all.

In mythical language Yahweh's incomparable position is described. Space is used here in mythical sense. It functions as third space to articulate the poet's belief. Space is used to describe a multi storey creation where God sits on his throne in heaven surrounded by heavenly beings. This mythical conceptualisation of Yahweh verbalises the belief in Yahweh's rule over everything and everybody in his creation. He is higher than even those in heaven who look down upon the earth and its inhabitants. Space is the vehicle to express this idea about God's superiority.

The mountains in verse 13 of the central strophe, created by God and praising him, form the meeting point between the heavenly abode from which God reigns over heaven and earth. They are not only landmarks indicating northern sanctuaries but represent an original Canaanite mythological ideology of God who reigns in heaven and descends to the world at the god mountain. In ideological terms these mountains are the point of contact between God's heavenly abode and the earth. He is lord of all and moves from the one to the other.

\footnotetext{
${ }^{1}$ h numa occurs in Ps 89 in vv 2, 3, 6, 9, 25, 34, 50.
} 


\subsection{Yahweh's acts and faithfulness (89:14-15)}

In the third strophe (89:14-15) the combination of power and faithfulness found in the first strophe (89:6-9) is repeated. God's acts are depicted by an indication of human body parts that are associated with power and strength. God has an arm with strength (89:14a), a strong hand, a lifted right hand (89:14b). This "trias" of arm, hand, and right hand is often used in other sections in the Bible to indicate God's saving acts in history.

The metaphorical indications of Yahweh's acts of power are parallel to the expressions of the quality of God's reign. His ruler ship is expressed in metaphorical-mythological terms in the first strophe (89:6-9) as the throne on which he sits to reign. It is qualified there in terms of righteousness-justice ( $f$ P mw $q d x$ ) and love-faithfulness (t mawds j ). In this strophe (89:14-15) his powerfull acts and reign on earth is also qualified in terms of justice and loyalty. Although no explicit spatial terms are found in this strophe, the semi mythological reference to his throne indicates that his relationship to those on earth is intended. No historical events are named, but a general remark on the way he exerts his power and reigns all the time over his underlings is made.

This strophe then echoes the heavenly space in the first strophe where Yahweh's ruler ship is also qualified in terms of his righteousness-justice and love-faithfulness via the central strophe in 89:10-13.

\subsection{The people (89:16-19)}

The scene in strophe four is that of people who worship God. Although no specific place is mentioned cultic space is intended. This strophe does not only refer to the cult centres at the mountains named in the central strophe, but also repeats the activity of praise by the mountains. Here we have people rejoicing in their God who reigns on earth as the source of their strength. The occasion is marked by the festal shout (89:16, $-h[w t)$, facing God, exulting in God's name and extolling his righteousness. The people's power is expressed in military terms as strength, preparedness for war, defensibility, and security. Yahweh's strength depicted in the previous strophe in terms of his arms, hand and exalted hand is repeated in the people's readiness to wage war. Because Yahweh is the God that he is, the God who is known for his righteousness and kindness towards his people, they can experience strength and rejoice in the Lord.

\subsection{Introduction (89:2-3)}

As previously remarked the movement in the hymn is from heavenly space (89:6-9), to earthly space (89:10-13), to the living space of human beings (89:14-15) and to the cultic space of God's people (89:16-19). Spatiality is 
used to conceptualise Yahweh's reign. Spatiality functions in mythological terms indicating a creation that includes inhabitable space in heaven and on earth. All through the creation from the heavens above to the earth down below Yahweh is experienced as God of faithfulness and loyalty. This theme is found in the introduction in 89:2-3. In the introduction the term "faithfulness"( $(\mathrm{nwma})$ and its synonym "steadfast love" (dsj $\mu \mid$ w $)$ are both repeated twice.

In the overall structure of the psalm this introduction is interrupted by verses 4-5 dealing with king David. This phrase on the king is put in an "envelope" position between verses 3 and 6 . The direct address to Yahweh in the introduction is resumed in verse 6 . The third person testimony-language in verse 2 is resumed in verse 7-8. The theme of the king in verses $4-5$ is taken up in the final line of the hymn in verse 19 and expounded in the oracle in verses 20-38. Saur (2004:160) sees verse 19 as "einer redaktionellen Modifikation der Verfasser" as this reference to the king was not part of the older tradition of the hymn. The introduction and the inclusion structure around verses 4-5 is the result of a later reworking of the hymn. The final line of the hymn in verse 19 and the inclusion were techniques used by the author(s) to link the royal theme in the oracle with the contents of the hymn.

At the end of the discussion of the hymn the conclusion can be drawn that the toponyms in verse 19 represent much more than mere geographical sites. Not only their northern locality but also the literary contexts of the hymn in which they are used indicate an ideological background. A northern Ugaritic provenance is indicated in which spatiality was used as means of conceptualising the reign of the god. The spatial structure of the hymn reflects the typical mythical view point from which all of creations were seen as primarily having its meaning in terms of Yahweh who created it and reigns over all of it. This substantiates our thesis that the translation "Zaphon and Jemin you created is the better translation."

\section{CONCLUSION}

The parallelism between verses $13 \mathrm{a}$ and $13 \mathrm{~b}$ indicates that these verses are to be translated in terms of each other. The strophe in which this verse operates (89:10-13) indicates a movement from heaven down to earth. This movement is also found in the structure of the hymn. Heavenly space (89:69), earthly space (89:10-13), living space of human beings (89:14-15) and cultic space (89:16-19) form a vertical line from above to below. An allinclusive creation is depicted in terms of a mythological spatial view in which Yahweh, heavenly beings and humans on earth are interrelated to each other. Ideological conceptualised third space is used in the hymn to sing the glory of 
God. Verse 13a has therefore to be translated against this background as "Zaphon and Yemin you created".

\section{Works Consulted}

Arav, R 1992. s v Hermon, Mount in Freedman, D N (ed), The Anchor Bible Dictionary, III, 158-160. New York: Doubelday,

Coetzee, P 1995. Waar is u liefdesdade van ouds, Here: 'n Eksegetiese verkenning van Psalm 89. BD Dissertation, University of Pretoria.

Flanagan, J W 1999. Ancient perceptions of space/perceptions of ancient space. Semeia 87, 15-43.

Goulder, M D 1982. The Psalms of the Sons of Korah. 51-84. Sheffield: JSOT Press. (JSOT Supp 20.)

Gray, J 1977. A cantata of the autumn festival: Psalm LXVIII, JSS 22, 2-26.

Gunkel, H 1981-1995. Texte aus der Umwelt des Alten Testaments I-III, (hrsg) van O Kaiser. Gütersloh.

Hossfeld, F-L 2000. Psalm 89, in Hossfeld, F-L \& Zenger, E, Psalmen 51-100, 576 601. Freiburg: Herder. (Herders Theologischer Kommentar zum Alten Testament.)

Jeremias, J 1987. Das Königtum Gottes in den Psalmen: Israels Begegnung mit dem kanaanäischen Mythos in den Jahwe-König-Psalmen, 29-45. Göttingen: Vandenhoeck \& Ruprecht.

Kavanagh, K 2000. Words in a cultural context, in Du Plessis, J C M D, Lexikos 10, 99-118. Stellenbosch: Buro van die WAT.

Kloos, C 1986. Yhwh's combat with the sea: A Canaanite tradition in the religion of ancient Israel. Asterdam: $\mathrm{G}$ A van Oorschot:

Koehler, L \& Baumgartner, W (eds) 1958. Lexicon in Veteris Testamenti Libros. Leiden: Brill.

Krauss, H-J 1966. Psalmen. 1 \& 2, Teilband. 3.Aufl. Neukirchen-Vluyn: Neukirchener Verlag.

Lisowsky,G 1958. Konkordanz zum Hebräishen Alten Testament, 2.Aufl. Stuttgart: Würtembergische Bibelanstalt.

Matthews, V H 2003. Physical space, imagined space, and "lived space" in ancient Israel. Biblical Theology Bulletin 33(1), 12-20.

Nickelsburg, G W E 1981. Enoch, Levi, and Peter: Recipients of revelation in upper Galilea. JBL 100(4), 575-600.

Mosca, P G 1986. Ugarit and Daniel: A missing link. Biblia 67, 496-517.

Petersen, C 1982. Mythos im Alten Testament: Bestimmung des Mythosbegriffs und Unterscuhung der mythischen Element in den Psalmen. Berlin: Walter de Gruyter.

Rudolph, W \& Rüger, H P 1984. Biblia Hebraica Stuttgartensia, 2.Aufl. Stuttgart: Deutsche Bibelgesellschaft.

Saur, M 2004. Die Königspsalmen: Studien zur Entstehung und Theologie. Berlin: Walter de Gruyter.

Seybold, K 1998. Studien zur Psalmenauslegung, 85-111. Stuttgart: Kohlhammer.

Seybold, K 2003. Poetik der Palmen. Stuttgart: Kohlhammer.

Tate, M E 1998. Psalms 51-100. Dallas, TX: Word Books. (Word Biblical Commentary 20.) 
The translation of Psalm 89:13 and its implications

Terrien, S 2003. The Psalms: Strophic structure and theological commentary. Grand Rapids, MI: Eerdmans.

Venter, P M 2004. Spatiality in Psalm 29, in Human, D J \& Vos C J A (eds), Psalms and liturgy. Sheffield: Sheffield Academic Press.

Weber, B 2003. Werkbuch Psalmen II: Die Psalmen 73 bis 150. Stuttgart: Kohlhammer.

Wilt, T 2002. A new framework for Bible translation, in Naude, J A \& Van der Merwe $\mathrm{C} \mathrm{H} \mathrm{J} \mathrm{(eds),} \mathrm{Contemporary} \mathrm{translation} \mathrm{studies} \mathrm{and} \mathrm{Bible} \mathrm{translation:} \mathrm{A} \mathrm{South}$ African perspective, 140-163. (Acta Theologica, Suppl 2.) 